\title{
Synthesis and Characterization of Novel Azo Disperse Dyes Containing a-amino Phosphonate and Their Dyeing Performance on Polyester Fabric
}

\author{
Mohamed A. Hamed ${ }^{1}$, Elkhabiry Shaban ${ }^{2 *}$, Hany Kafafy ${ }^{2}$, Ahmed Abdel Aleem \\ El Gokha ${ }^{3}$ and Ibrahim El Sayed ${ }^{3}$ \\ ${ }^{1}$ Chemistry Department, Faculty of Science, Tanta University, Tanta. ${ }^{2}$ Dyeing, Printing \\ and Textile Auxiliaries Department, Textile Research Division, National Research \\ Centre, 33 El-Bohouth Street, Dokki, Giza 12622. \\ ${ }^{3}$ Chemistry Department, Faculty of Science, El Menoufeia University, Shebin El \\ Koom, Egypt.
}

\begin{abstract}
$T^{1}$ HREE novel azo disperse dyes were designed, synthesized, and characterized by utilizing of $\alpha$-aminophosphonates chromophores. The target compounds were prepared by employing of benzidine as amine and different heterocyclic formyl as aldehyde, and triphenylphosphite $\mathrm{P}\left(\mathrm{OC}_{6} \mathrm{H}_{5}\right)_{3}$ that gives a-aminophosphonate in one position and free amino group in the other position, which was then coupled with $\beta$-naphthol to give the target products azo disperse dyes. The prepared dyes were structurally confirmed by IR, ${ }^{1} \mathrm{HNMR}$ and mass spectral data and applied to polyester fabric as azo disperse dyes and all fastness properties for the dyed samples were measured.
\end{abstract}

Keywords: $\alpha$-aminophosphonates, Azo disperses dyes, Benzidine and polyester fabric.

\section{Introduction}

Polyester fabrics are the most demanded fabrics in the textile industry and disperse dyes are most important class of dyes for dyeing such fabrics because of its brilliance color, wide color range, stable fastness properties, environmental and economic reasons as well[1].

Organophosphorus compounds are important substrates and exhibit a wide range of biological activities. Organophosphorus intermediates are involved in many areas of agricultural, medicinal chemistry, and industrial applications due to their biological and physical properties[2-3]. $\alpha$-Functionalized phosphonic acids are important intermediates for synthetic intermediates and preparation of many compounds as well [4-6].

Among $\alpha$-functional phosphonic acids, $\alpha$-aminophosphonic acids, and $\alpha$-amino phosphonate are supreme important compounds which provides a diversity of important and preferable properties. A considerable number of $\alpha$-amino phosphonate derivatives are known to be bioactive, they display an antiviral, antibacterial, antifungal, antimicrobial and antitumor activity [7-16].

In addition, the Organophosphorus compounds are very important precursors for preparation of fused heterocyclic compounds, Organophosphorus precursors owing great biological and pharmacological activities [17-20], which could be used as intermediates in the dyestuff industry [1, 2123].

We also focused on whether bifunctional group like $\alpha$-amino phosphonate located on the spacer of the azo dye moiety, would stimulate and expected to exhibit high acceptable and good biological resistance, in order to get colored sterile and/or biological resisting textile which could be applied in various fields of life applications.

In current study we used a one-pot KabachnikFields reaction of different aryl substituted pyrazolaldehydes, benzidine, triphenylphosphite, by using Lewis acid catalyst such as copper(II) triflate $\mathrm{Cu}\left(\mathrm{OSO}_{2} \mathrm{CF}_{3}\right)_{2}$ in dichloromethane which facilitate the condensation reaction at room temperature. A reaction of diphenyl [benzidine]1aminoheterocyclicphosphonate coupled with $\beta$

*Corresponding author e-mail: Shaban_nrc@yahoo.com 
-naphthol was done to prepare 2-Naphthol-azodiphenyl [benzidine] amino heterocyclic phosphonate compounds. The prepared compounds as disperse dyes were used for the application of dyeing polyester fabric with complete testing of fastness properties.

\section{Results and Discussion}

\section{Synthesis}

The Synthesis of novel azo disperses dyes containing $\alpha$-aminophosphonates were achieved with high yields. While the synthetic routes of the target compounds were carried out by employing of benzidine as amine and aryl substituted pyrazolaldehydes, triphenylphosphite through copper (II) triflate $\mathrm{Cu}\left(\mathrm{OSO}_{2} \mathrm{CF}_{3}\right)_{2}$ as lewis acid catalyst in dry dichloromethane at room temperature using one-pot Kabachnik-Fields reaction to afford $\alpha$-aminophosphonate in one position and free amino group as shown in Scheme 1.

The free amino group was coupled with $\beta$ naphthol to produce different azo disperse dyes as shown in Scheme 2. The chemical structures, molecular formula, and the physical properties of synthesized dyes (D1-3) are shown in Table 1 , and the prepared dyes were subjected for application of dyeing polyester fabric, and the fastness properties for the prepared dyes were also measured.

In addition, dyed polyester fabric colorimetric parameters were assessed by colorimetric measurements using reflectance spectrophotometer (Gretag Macbeth CE 7000a) (Table 2).
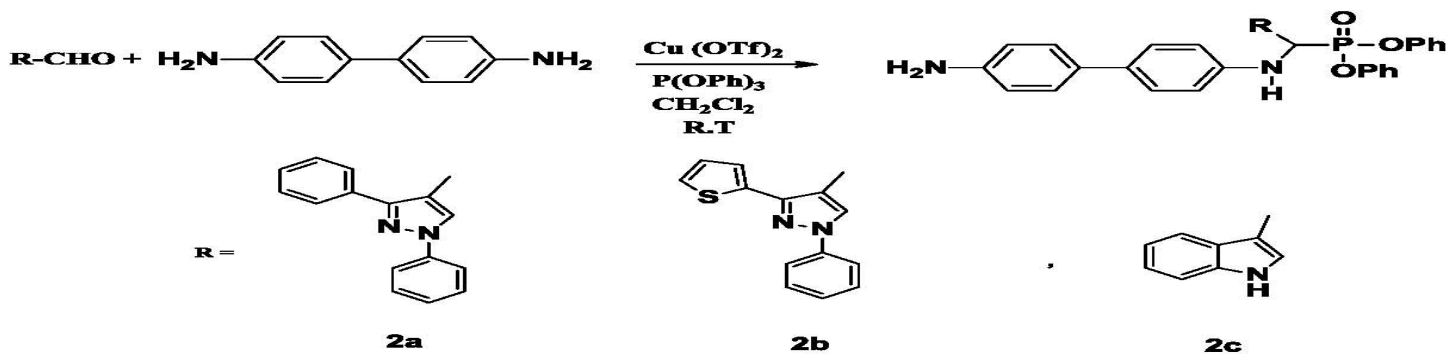

Seheme 1

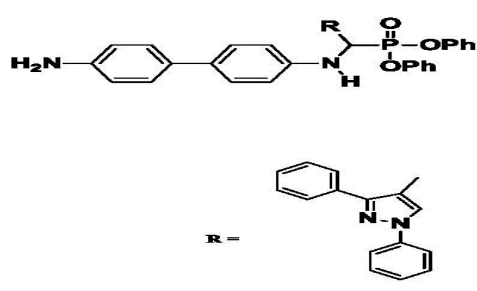

D1

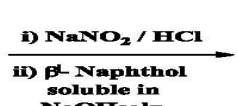
soluble in
NaOtsoln<smiles>CC1(C)CC(c2ccccc2)N=C1c1cccs1</smiles>

$\mathbf{D 2}$
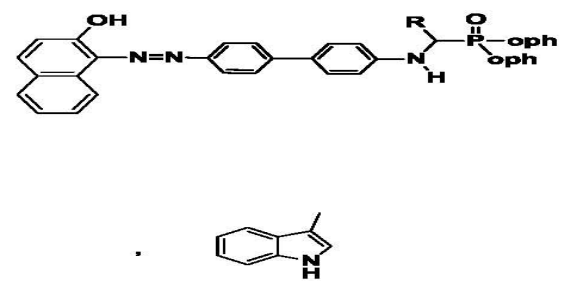

D3

TABLE 1. Physical data for azo disperse dyes (D1-3).

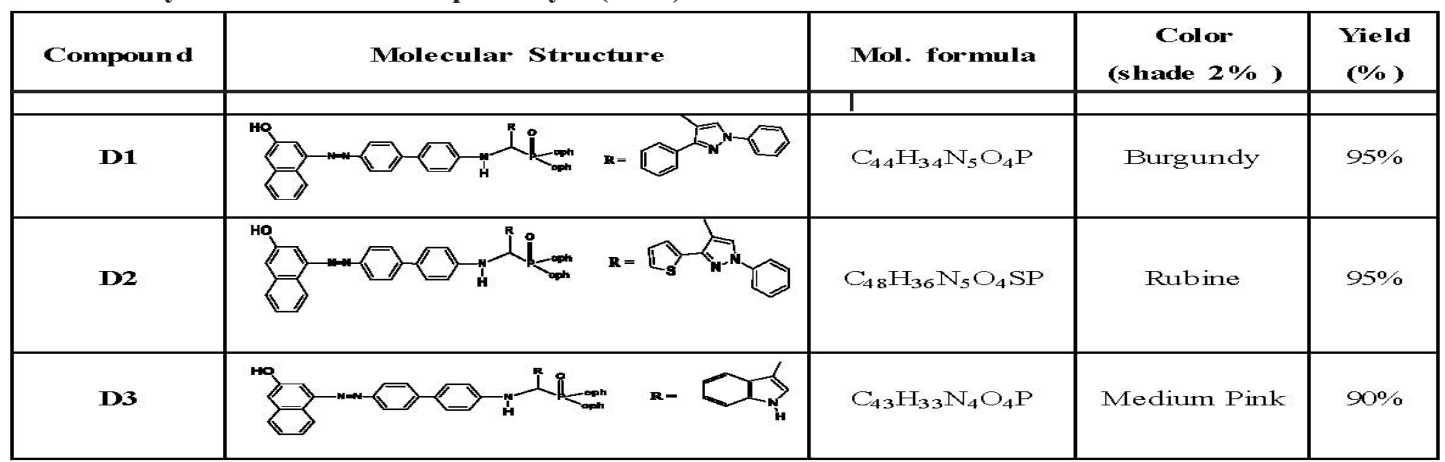

Egypt.J.Chem. Special Issue (2017) 
TABLE 2. Color assessment of the dyes.

\begin{tabular}{cccccc}
\hline Dye & $\begin{array}{c}\text { Absorption } \\
{\left[\lambda_{\max }(\mathbf{n m})\right]}\end{array}$ & $\mathbf{K} / \mathbf{S}$ & $\mathbf{L}^{*}$ & $\mathbf{a}^{*}$ & $\mathbf{b}^{*}$ \\
\hline D1 & 505 & 30.03 & 60.15 & 43.12 & 36.06 \\
D2 & 502 & 26.17 & 44.33 & 19.22 & 24.13 \\
D3 & 385 & 18.33 & 45.14 & 22.45 & 19.03 \\
\hline
\end{tabular}

$\mathrm{K} / \mathrm{S}$ values given by the reflectance spectrometer are calculated at $\lambda_{\text {max }}$ and are directly correlated with the dye concentration on the dye substrate according to the Kubelka-Munk equation [29]: $\mathrm{K} / \mathrm{S}=(1-\mathrm{R}) 2 / 2 \mathrm{R}$, where $\mathrm{K}=$ absorbance coefficient, $\mathrm{S}=$ scattering coefficient, $\mathrm{R}=$ reflectance ratio.

Fastness tests for the prepared dyes (D1-3)

The prepared set of dyes (D1-3) was applied on dyeing of polyester fabric.

Fastness properties were measured according to ISO 105-X12(1987), ISO 105-co4 (1989), ISO105-EO4 (1989), ISO 105-BO2 (1988) corresponding to color fastness to rubbing, sublimation, washing, acid and alkali perspiration, respectively, for the fastness assessments, a rating scale of 1 (poor) to 5 (excellent) was used.

Table 3 shows that, all the dyed polyester fabric using D1-3 dyes exhibit good to very good washing fastness. On the other hand light fastness tests were carried out (According to the blue scale) and affected in the coupling component by the substituents. Mostly, better light fastness (good, 4-5 of the blue wool standard scale 18) $4 \mathrm{~h}$ irradiation to the dyed samples using a XENOTEST 1200 apparatus at a relative air humidity of $65 \%$ and $50^{\circ} \mathrm{C}$ with duration 4 hours and the dyed samples showed very good light fastness. WhileTable 4 showed fairly good wet and very good dry rubbing fastness, the sublimation fastness for the dyed polyester fabric exhibit fairly good to poor sublimation resistance.

Fastness tests for acid and alkali perspiration were also performed and results are recorded in Table 5, it is clear from the results as it seen in Table 5 that all dyed polyester fabric are of fairly good to very good resistance acid and alkali perspiration properties.

TABLE 3. Washing and light fastness results for azo disperse compounds (D1-3).

\begin{tabular}{|c|c|c|c|c|}
\hline \multirow{2}{*}{ Dye } & \multirow{2}{*}{ Color (shade $2 \%$ ) } & \multicolumn{2}{|c|}{ Washing fastness } & \multirow{2}{*}{ Light fastness } \\
\hline & & ALT. & ST. & \\
\hline D1 & Purgundy & 4 & 4 & 6 \\
\hline D2 & Rubin & 4 & $4-5$ & 6 \\
\hline D3 & Medium pink & 4 & $4-5$ & 6 \\
\hline
\end{tabular}

TABLE 4. Rubbing and sublimation fastness for azo disperse compounds (D1-3).

\begin{tabular}{cccccc}
\hline \multirow{2}{*}{ Dye } & \multirow{2}{*}{ Color (shade 2\%) } & \multicolumn{2}{c}{ Rubbing fastness } & \multicolumn{2}{c}{ sublimation fastness } \\
\cline { 3 - 6 } & Purgundy & Dry & wet & ALT. & ST. \\
\hline D1 & Rubin & $4-5$ & $3-4$ & $3-4$ & 4 \\
D2 & Medium pink & $4-5$ & 4 & 4 & $3-4$ \\
D3 & & 4 & $4-5$ & $4-5$ & 4 \\
\hline
\end{tabular}

ALT. $=$ Alteration, $\quad$ ST. $=$ Staining on cotton.

TABLE 5. Acidic and alkaline perspiration for azo disperse dyes (D1-3).

\begin{tabular}{cccccc}
\hline \multirow{2}{*}{ Dye } & \multirow{2}{*}{ Color (shade 2\%) } & \multicolumn{2}{c}{ Acidic perspiration } & \multicolumn{2}{c}{ Alkaline perspiration } \\
\cline { 3 - 6 } & BLT. & ST. & ALT. & ST. \\
\hline D1 & Burgundy & $4-5$ & $3-4$ & $3-4$ & 4 \\
D2 & Rubine & 4 & $3-4$ & 4 & $3-4$ \\
D3 & Medium pink & 4 & 4 & $3-4$ & $4-5$ \\
\hline
\end{tabular}

ALT. $=$ Alteration $\quad$ ST. $=$ staining on cotton. 


\section{Conclusion}

In this work, we have synthesized three novel azo disperse dyes containing $\alpha$-aminophosphonates, and $\beta$-naphthol as coupling compound to give the target azo disperse dyes. The prepared dyes were used as disperse dyes for polyester fabric dyeing. These dyes gave a wide range of colors varying from burgundy, rubine, and medium pink shades on the fabric. The light, sublimation, washing, rubbing, and perspiration fastness of all patterns dyed with the prepared azo disperse dyes show good to very good fastness properties. In addition, the dyed samples showed that the dyes have good affinity with moderate to very good brightness and color depth to polyester fabric.

\section{Experimental}

All ${ }^{1} \mathrm{HNMR}$ experiments (solvent DMSO) were carried out with a $400 \mathrm{MHz}$ Bruker Avance DRX-400 spectrometer at Okayama University, Japan. Chemical shifts are reported in part per million (ppm) relative to the respective solvent or tetramethylsilane (TMS). Melting points were recorded on Stuart scientific melting point apparatus and are uncorrected.

The mass spectroscopy and the microanalysis were performed in microanalysis laboratory at Cairo University. All reactions were followed by thin layer chromatography (TLC) on kiesel gel F254 precoated plates (Merck). Anhydrous THF, $\mathrm{MeOH}$ and $\mathrm{CH}_{2} \mathrm{Cl}_{2}$ were obtained from SigmaAldrich.

Synthesis of $\alpha$-aminophosphonates $2 a-2 c$

Aryl substituted pyrazolaldehydes (1.2 $\mathrm{mmol})$, benzidine $(1 \mathrm{mmol})$ and triphenylphosphite were dissolved in well dried anhyd. $\mathrm{CH}_{2} \mathrm{Cl}_{2}(5 \mathrm{ml})$. The lewis acid, copper (II) triflate (10 mol \%) was added in one portion. The mixture was stirred at RT, until TLC analysis showed the complete consumption of benzidine. Then $\mathrm{CH}_{2} \mathrm{Cl}_{2}$ was evaporated and the solid precipitated was filtered, dried, and crystallized from methanol as shown in Scheme 1.

Diphenyl(((4'-amino-[1,1'-biphenyl]-4-yl) amino)(1,3-diphenyl-1H-pyrazol-4-yl)methyl) phosphonate

$\mathrm{C}_{40} \mathrm{H}_{33} \mathrm{~N}_{4} \mathrm{O}_{3} \mathrm{P}$, Yield $(95 \%) ; \mathrm{mp}>300^{\circ} \mathrm{C} .{ }^{1} \mathrm{HNMR}$ (DMSO , $400 \mathrm{MHz}): \delta=5.08$ (s, 1H, CHP) , 5.29 (s, 1H, NH), 5.99 (d, $J=6.0 \mathrm{~Hz}, \mathrm{NH}_{2}$ ), $7.02-7.68$ (m, $\mathrm{CH}$ arom ) ,8.28( s, CH pyrazole ). The mass spectra show the molecular ion peak at $\mathrm{m} / \mathrm{e}=650$
$\left(\mathrm{M}^{+}+2,9.5 \%\right)$, the ion Peak at $\mathrm{m} / \mathrm{e}=77\left(\mathrm{M}^{+}\right.$ $-\mathrm{C}_{34} \mathrm{H}_{28} \mathrm{~N}_{4} \mathrm{O}_{3} \mathrm{P}, 98.4 \%$ ), the ion peak at $\mathrm{m} / \mathrm{e}=91$ $\left(\mathrm{M}^{+}-\mathrm{C}_{34} \mathrm{H}_{28} \mathrm{~N}_{3} \mathrm{O}_{3} \mathrm{P}, 23.8 \%\right)$

Diphenyl(((4'-amino-[1,1'-biphenyl]-4-yl) amino)(1-phenyl-3-(thiophen-2-yl)-1H-pyrazol4-yl)methyl)phosphonate,

$\mathrm{C}_{38} \mathrm{H}_{31} \mathrm{~N}_{4} \mathrm{O}_{3} \mathrm{PS}$, Yield $(85 \%) ; \mathrm{mp}>300^{\circ} \mathrm{C}$. ${ }^{1} \mathrm{HNMR}$ (DMSO , $\left.400 \mathrm{MHz}\right): \delta=5.40(\mathrm{~s}, 1 \mathrm{H}$, CHP), $5.80(\mathrm{~s}, 1 \mathrm{H}, \mathrm{NH}), 6.05\left(\mathrm{~d}, J=6.0 \mathrm{~Hz}, \mathrm{NH}_{2}\right)$, 6.55-6.60 (m, 4H arom ), 7.33-7.80 (m, CH arom )8.33( s, CHpyrazole ). The mass spectra show the molecular ion peak at $\mathrm{m} / \mathrm{e}=655\left(\mathrm{M}^{+}+1,9.4 \%\right)$, the ion Peak at $\mathrm{m} / \mathrm{e}=77\left(\mathrm{M}^{+}-\mathrm{C}_{34} \mathrm{H}_{28} \mathrm{~N}_{4} \mathrm{O}_{3} \mathrm{P}, 98.4\right.$ $\%)$, the ion peak at $\mathrm{m} / \mathrm{e}=97\left(\mathrm{M}^{+}-\mathrm{C}_{34} \mathrm{H}_{28} \mathrm{~N}_{3} \mathrm{O}_{3} \mathrm{P}\right.$, $33.8 \%$ )

Diphenyl(((4'-amino-[1,1'-biphenyl]-4-yl) amino)(1H-indol-3-yl)methyl)phosphonate, $\mathrm{C}_{33} \mathrm{H}_{28} \mathrm{~N}_{3} \mathrm{O}_{3} \mathrm{P}, \quad$ Yield (85\%); mp $280-282^{\circ} \mathrm{C}$. ${ }^{1} \mathrm{HNMR}$

(DMSO , $400 \mathrm{MHz}): \delta=4.73(\mathrm{~s}, 1 \mathrm{H}, \mathrm{CHP})$, $5.30(\mathrm{~s}, 1 \mathrm{H}, \mathrm{NH}), 6.22\left(\mathrm{~d}, J=6.0 \mathrm{~Hz}, \mathrm{NH}_{2}\right), 6.40$ 6.58 ( $\mathrm{m}, 4 \mathrm{H}$ arom ) , 7.20-7.58 ( $\mathrm{m}, \mathrm{CH}$ arom ) 9.66( $\mathrm{s}, \mathrm{NH})$. The mass spectra show the molecular ion peak at $\mathrm{m} / \mathrm{e}=546\left(\mathrm{M}^{+}+1,9.6 \%\right)$.

General procedure for the synthesis of diphenyl 1 [(benzidine) 1-azo $\beta$-Naphthole] aminoheterocyclephosphonate

A well-stirred solution of diphenyl [benzidine] 1-amino heterocylicphosphonate (2a-2c) (1.02 $\mathrm{mmol})$ in $2 \mathrm{~N} \mathrm{HCl}(1.5 \mathrm{~mL})$ was cooled in ice salt bath and diazotized with $1 \mathrm{~N} \mathrm{NaNO}_{2}$ solution ( $1 \mathrm{mmol}$; in $2 \mathrm{~mL}$ water). The mixture was then tested for complete diazotization using starch iodide paper, which gives a weak blue test. If the mixture does not give the test, more sodium nitrite was added dropwise until a positive test is obtained and the color is stable for few minutes. If, on the other hand, strong test for nitrite is obtained, a few drops of a dilute solution of the base hydrochloride are added until the nitrite test is nearly negative. The above cold diazonium solution was added slowly to a well stirred solution to $\beta$ - Naphthole (1mmol) in ethanol $(20 \mathrm{~mL})$ containing sodium acetate $(2.5 \mathrm{mmol})$ and the mixture was cooled in an ice salt bath. After the addition of the diazonium salt solution the reaction was tested for coupling reaction. A drop of the reaction mixture was placed on a filter paper and the colorless ring surrounding the spot dye was treated with a drop of an alkaline solution of a reactive coupler, such as sodium salt of 3-hydroxy-2-naphthanilide. If un-reacted diazonium salt is present, a dye is formed. The 
presence of un-reacted coupler can be determined in a similar manner using a diazonium salt solution to test the colorless ring. After the coupling reaction is complete, the reaction mixture was stirred for 50 minutes at room temperature. The crude product was filtered, dried and Purified by silica gel column chromatography (Ethyl acetate: Hexane 3:1) to give the dye.

Diphenyl((1,3-diphenyl-1H-pyrazol-4-yl) ((4'-((2-hydroxynaphthalen-1-yl)diazenyl)-[1,1'biphenyl]-4-yl)amino)methyl)phosphonate D1

$\mathrm{C}_{50} \mathrm{H}_{38} \mathrm{~N}_{5} \mathrm{O}_{4} \mathrm{P}$,Yield (95\%); m.p $=275-277^{\circ} \mathrm{C}$. IR $(\mathrm{KBr}) \mathrm{cm}^{-1}: \mathrm{OH}$ at $3716 \mathrm{~cm}^{-1}, 3429(\mathrm{NH})$, $1594(\mathrm{~N}=\mathrm{N}), 1227(\mathrm{P}=\mathrm{O})$, and $1027(-\mathrm{P}-\mathrm{O}-\mathrm{C}$ ). ${ }^{1} \mathrm{HNMR}$ (DMSO, $\left.400 \mathrm{MHz}\right): \delta=4.9(\mathrm{~s}, 1 \mathrm{H}$, CHP), 8.6 (s, 1H, NH), $7.1-7.29$ (m, 5H arom), $7.29-7.9$ (m, CH arom), 9.9(s, 1H, OH).

Diphenyl(((4'-((2-hydroxynaphthalen-1-yl) diazenyl)-[1,1'-biphenyl]-4-yl)amino)(1-phenyl3-(thiophen-2-yl)-1H-pyrazol-4-yl)methyl) phosphonate

D2: $\mathrm{C}_{48} \mathrm{H}_{35} \mathrm{~N}_{5} \mathrm{O}_{4} \mathrm{SP}$, Yield (95\%); m.p $=325$ $-327{ }^{\circ} \mathrm{C}$. ${ }^{1} \mathrm{HNMR}$ (DMSO, $\left.400 \mathrm{MHz}\right): \delta=4.1$ (s, 1H, CHP), 8.9 (s, 1H, NH), $6.55-6.88$ (m, 2H arom), $7.29-7.9$ (m, CH arom), 10.4(s, 1H, OH). The mass spectra show the molecular ion peak at $\mathrm{m} / \mathrm{e}=809\left(\mathrm{M}^{+}, 42.9 \%\right)$, the ion Peak at $\mathrm{m} / \mathrm{e}=808$ $\left(\mathrm{M}^{+}-1,35.7 \%\right)$, the ion peak at $\mathrm{m} / \mathrm{e}=810\left(\mathrm{M}^{+}+1\right.$, $21.4 \%$ )

Diphenyl(((4'-((2-hydroxynaphthalen-1-yl) diazenyl)-[1,1'-biphenyl]-4-yl)amino)(1H-indol3-yl)methyl)phosphonate

D3: $\mathrm{C}_{43} \mathrm{H}_{33} \mathrm{~N}_{4} \mathrm{O}_{4}$ P, Yield (95\%); m. $\mathrm{p}=240$ $241^{\circ} \mathrm{C}$. The mass spectra show the molecular ion peak at $\mathrm{m} / \mathrm{e}=700\left(\mathrm{M}^{+}, 0.3 \%\right)$, the base ion Peak at $\mathrm{m} / \mathrm{e}=322\left(\mathrm{M}^{+}-\mathrm{C}_{21} \mathrm{H}_{19} \mathrm{~N}_{2} \mathrm{O}_{3} \mathrm{P}, 100 \%\right)$, the ion peak at $\mathrm{m} / \mathrm{e}=77(62.4 \%)$

Substrate

Commercially available scoured, woven polyester fabric with weight of $\left(122 \mathrm{~g} \mathrm{~m}^{-2}\right)$ was used for the experiment assess the dyeing behavior of the compounds under investigation.

\section{Dyeing of polyester fabric}

Azoic dyes (D1, D2, and D3) were applied on dyeing polyester $100 \%$ fabric that was performed by the following procedure:

- The required amount of the dye ( $2 \%$ shade ) was suspended in methanol and was added dropwise to a stirred pollution of Dispersogen $\mathrm{P}(100 / \mathrm{L})$ [ dispersing agent of Hoechst ].

- A sample of polyester fabric $(100 \%)$ was immersed in a bath of $50^{\circ} \mathrm{C}$ for $5 \mathrm{~min}$. with a liquor ratio $1: 20$.

- $2 \mathrm{~g} / \mathrm{L}$ Eganal RAP ( Levelling agent of Hoechst) and $4 \mathrm{~g} / \mathrm{L}$ Hostatex Lo - ET ( carrier of Hoechst) were added to the bath with stirring for $10 \mathrm{~min}$. The $\mathrm{PH}$ is adjusted to 4-5 with the addition of acetic acid.

- The thoroughly dispersed dye solutions were added to the bath and the temperature is raised at $98{ }^{\circ} \mathrm{C}$ within $60 \mathrm{~min}$. Total dyeing time is then being $90 \mathrm{~min}$.

- Afterwards it is cooled to $60{ }^{\circ} \mathrm{C}$ and is supplied to washing, dyed samples rinsed and dried.

Color assessment

The colorimetric parameters (Table 2) of the dyed polyester fibers were determined on a reflectance spectrophotometer (Gretag-Macbeth CE 7000a), equipped with a $\mathrm{D} 65 / 10^{\circ}$ source and barium sulphate as standard blank, UV excluded, specular component included and three repeated measurements average settings. The following CIELAB coordinates are measured, lightness ( $\left.\mathrm{L}^{*}\right)$, chroma $\left(\mathrm{C}^{*}\right)$, hue angle from $0^{\circ}$ to $360^{\circ}(\mathrm{H}),\left(\mathrm{a}^{*}\right)$ value represents the degree of redness (positive) and greenness (negative) and $\left(b^{*}\right)$ represents the degree of yellowness (positive) and blueness (negative). A reflectance spectrophotometer (Gretag Macbeth CE 7000a) was used for the colorimetric measurements on the dyed samples.

\section{Color measurements}

Fastness tests for the prepared dyes (D1-3)

The prepared set of dyes (D1-3) was applied on dyeing of polyester fabric: The dyed washed samples were tested by standard ISO methods. The specific tests were ISO 105-X12(1987), ISO 105-co4 (1989), ISO105-EO4 (1989), ISO 105-BO2 (1988) corresponding to color fastness to sublimation, rubbing, washing, perspiration, respectively, and light which was measured using samples $10 \times 10 \mathrm{~cm}$ of dyed fabrics mounted on a white chart paper and irradiated using a XENOTEST 1200 apparatus at a relative air humidity of $65 \%$ and $50^{\circ} \mathrm{C}$ with duration 4 hours.

\section{References}

1. Metwally M., Ebrahim A., Amira M., and Fathy A. Amer, New azodisperse dyes with thiazole, thiophene, pyridone and pyrazolone moiety for dyeing polyester fabrics. Dyes and Pigments, 92(3), 902-908 (2012). 
2. Kafarski P. and Lejczak B., Aminophosphonic acids of potential medical importance. Current Medicinal Chemistry-Anti-Cancer Agents, 1(3), 301-312 (2001)

3. Berlicki L. and Kafarski P., Computer-aided analysis and design of phosphonic and phosphinic enzyme inhibitors as potential drugs and agrochemicals. Current Organic Chemistry, 9(18), 1829-1850 (2005).

4. Rozenfeld, Xavier I., Mayumi O., Bernard M. and Catherine L., Contribution of molecular modeling and site-directed mutagenesis to the identification of a new residue, glutamate 215 , involved in the exopeptidase specificity of aminopeptidase $A$. Biochemistry, 42(50),14785-14793 (2003).

5. Kafarski P. and Lejczak B., Application of bacteria and fungi as biocatalysts for the preparation of optically active hydroxyphosphonates. Journal of Molecular Catalysis B: Enzymatic, 29(1), 99-104 (2004).

6. Kafarski P., Kafarski P., Lejczak B., Forlani G., Gancarz R., Torreilles C., Grembecka J., Ryczek A. and Wieczorek P., Herbicidal derivatives of aminomethylenebisphosphonic acid. Part III. Structure - activity relationship. Journal of plant growth regulation, 16(3),153-158 (1997).

7. Fields S.C., Synthesis of natural products containing a $\mathrm{C} \square \mathrm{P}$ bond. Tetrahedron, 55(42), 12237-12273 (1999).

8. Van der Veken P., El Sayed I., Joossens J., Stevens C.V. , Augustyns K. and Haemers A., TheLewis acid catalyzed synthesis of N-protected diphenyl 1- aminoalkylphosphonates, Synthesis, 634-638 (2005).

9. Grassert I., Schmidt U., Ziegler S., Fischer C. and Günther Oehme, Use of rhodium complexes with amphiphilic and nonamphiphilic ligands for the preparation of chiral $\alpha$-aminophosphonic acid esters by hydrogenation in micellar media. Tetrahedron: Asymmetry, 9(23), 4193-4202 (1998).

10. Lintunen T. and Yli-Kauhaluoma J.T., Synthesis of aminophosphonate haptens for an aminoacylation reaction between methyl glucoside and a $\beta$-alanyl ester. Bioorganic \& Medicinal Chemistry Letters, 10(15),1749-1750 (2000).

11. Wenshe L., Claude J. Rogers, Andrew J. Fisher, and Michael D. Toney, Aminophosphonate inhibitors of dialkylglycine decarboxylase: structural basis for slow binding inhibition. Biochemistry, 41(41),
12320-12328 (2002).

12. De Risi, C., Daniela P., Alessandro D., Gian P. Pollini and Valerio Bertol, a new and expedient diastereoselective synthesis of $\alpha$-(hydroxyamino) phosphonates and $\alpha$-aminophosphonates by silyl triflate promoted diethyl phosphite addition to chiral n-benzyl nitrones. European Journal of Organic Chemistry, 2003(10),1904-1914 (2003).

13. Grembecka J., Mucha A., Cierpicki T. , Kafarski P., The most potent organophosphorus inhibitors of leucine aminopeptidase. Structure-based design, chemistry, and activity. Journal of Medicinal. Chemistry. 46,2641-2655 (2003).

14. Maghsoodlou T.M., Sayyed M.H., Reza H., Nourallah H., Seyed S. Sajadikhah and Mohsen R., An efficient and simple synthesis of $\alpha$-amino phosphonates as 'drug like' molecules catalyzed by silica-supported perchloric acid ( $\mathrm{HClO} 4-$ SiO2). Arabian Journal of Chemistry, 4(4),481485 (2011).

15. Cen W. and Shen Y., New synthesis of fluorinated 2-aminophosphonates. Journal of Fluorine Chemistry, 72(1), 107-110 (1995).

16. Buck R.T., Paul A. Clarke, Diane M. Coe, and Martin J. Drysdale, The carbenoid approach to peptide synthesis. Chemistry- European Journal, 6(12),2160-2167 (2000).

17. Du S., Faiger H., Belkhov V. and Baasov T., Towards the development of novel antibiotics: synthesis and evaluation of a mechanism-based inhibitor of Kdo8P synthase. Bioorg. Med. Chem. 7, 2671-2682 (1999).

18. Atherton F.R., Hassal C. H. and Lambert R.W., Synthesis and structure-activity relationships of antibacterial phosphonopeptides incorporating (1-aminoethy1)phosphonic acid and (aminomethy1)phosphonic acid. Journal of Medicinal. Chemistry., 29(1), (1986).

19. Lukevics, E., Arsenyan P., Germane S. and Shestakova I., Neurotropic and antitumor activities of silyl-and germyl-isoxazolin-2-yl derivatives. Applied organometallic Chemistry, 13(10), 795798 (1999).

20. Swarna A. Gamage, Julie A. Spicer, Gordon W. Rewcastle, John M., Sukhjit S.1, Wendy D., Prakash M., Nigel V. Peter A. Charlton and William A. Denny, Structure- activity relationships for pyrido-, imidazo-, pyrazolo-, pyrazino-, and pyrrolophenazinecarboxamides as topoisomerase- 
targeted anticancer agents. Journal of medicinal Chemistry, 45(3), 740-743 (2002).

21. Mohamed A. Metwally, Amira M., Ebrahim A., and Fathy A. Amer, Substituted 5-antipyrinylazo4-phenyl-2-aminothiazoles as disperse dyes for dyeing polyester fabrics. Monatshefte für Chemiel Chemical Monthly, 139(1), 35-42 (2008).

22. Metwally M.A. , Abdel-latif E., Khalil A.M.,
Amer F.A. and Kaupp G. , New azodisperse dyes with thiazole ring for dyeing polyester fabrics. Dyes and Pigments, 62(2),181-195 (2004).

23. El-Gokha, A. and Maas G., (2-Formyl-1phenylcyclopropyl) phosphonates as building blocks for (2-aminomethyl-cyclopropyl) phosphonates. Tetrahedron, 67(16), 2849-2857 (2011).

(Received 27/8/2017; accepted 15/11/2017)

\section{تحضير وتوصيف صبغات ازو مشتثة جديدة تحتوي علي مجموعة الفا امينوفوسفات وتطبيقاتها في صباغة الياف البولي استر

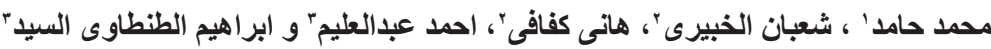

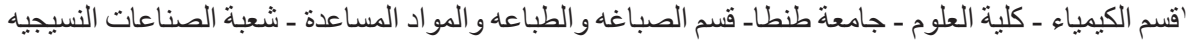

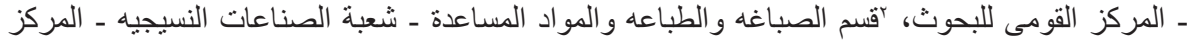 القومى للبحوث و "قنسم الكيمياء ـ كلية العلوم - جامعة المنوفيةـ قسم الكيمياء ـ كلية العلوم - جامعة المنوفية ـ}

يهدف هذ البحث الي تحضير صبغات ازو مشتتة جديدة مبنية علي مركبات البنزيدين و الحاملة لمجمو عة الفا امينو فوسفات التي تتميز بنشاطها البيولوجى المتتوع وتطبيق هذه الصبغات فئنة في صباغة البنة الياف البولي اسنر.

فى هذا البحث تم تحضير وتوصيف عدة صبغات ازو مشتتة جديدة باستخدام مركبات البنزيدين المحتوي

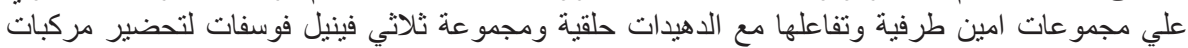

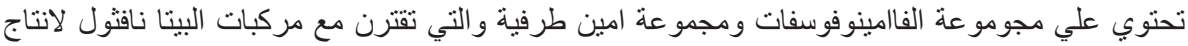
صبغات ازو مشتتة جديدة.

تم توصيف كل الصبغات الجديدة باستخدام اجهزة ( IR, ${ }^{1} \mathrm{HNMR}$ ( Mass spectra)

تم تطبيق الصبغات المحضرة في صباغة الياف البولي استر كما تم قياس خو اص الثبات للالياف المصبو غة

وقد اعطت نتائج جيدة. 